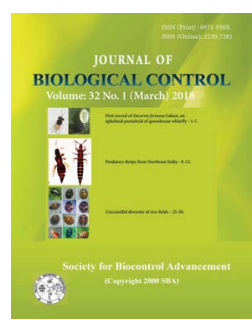

Research Article

\title{
First record of Encarsia formosa Gahan, an aphelinid parasitoid of greenhouse whitefly from India and its dynamics on tomato grown under protected environment
}

\author{
VINAY SINGH and A. K. SOOD* \\ Department of Entomology, CSK Himachal Pradesh Agricultural University, Palampur - 176062, Himachal Pradesh, \\ India \\ *Corresponding author's E-mail: sood_hpau@yahoo.co.in
}

\begin{abstract}
Greenhouse whitefly, Trialeurodes vaporariorum (Westwood) is a key pest of tomato under protected environment in Himachal Pradesh. Recently, an aphelinid parasitoid, Encarsia formosa Gahan was observed to parasitize T. vaporariorum in mid-hill regions of Himachal Pradesh. It seems to be the first record of this aphelinid parasitoid from India. Population buildup of $E$. formosa was recorded in eight insecticide based greenhouse whitefly management modules comprising soil application of imidacloprid (0.009\%) and foliar applications of spiromesifen $(0.02 \%)$, thiamethoxam $(0.01 \%)$ and azadirachtin $(0.0003 \%)$ in tomato grown during summer cropping seasons of 2015 and 2016 under naturally ventilated polyhouse. Parasitization by E. formosa in the plants without treatment varied from 31.8 to 81.2 and 36.8 to 93.6 per cent during 2015 and 2016, respectively. The insecticidal module comprising single soil application of imidacloprid one day after transplanting followed by alternate foliar applications of azadirachtin starting 45 days after transplanting at 10 days interval proved favourable for buildup of E. formosa as compared to other insecticide based greenhouse whitefly management modules during both the seasons. Based on the observations recorded, it was observed that the parasitoid has the potential for inclusion in greenhouse whitefly management programme.
\end{abstract}

KEY WORDS: Encarsia formosa, management, protected cultivation, Trialeurodes vaporariorum

(Article chronicle: Received: 06-07-2017; Revised: 10-01-2018; Accepted: 03-02-2018)

\section{INTRODUCTION}

The greenhouse whitefly, Trialeurodes vaporariorum (Westwood) (Hemiptera: Aleyrodidae) is a serious pest intemperate regions under protected cultivation situations and in field crops where the summers are warm enough (Byrne and Bellows, 1991; Sood and Sood, 2004). In Himachal Pradesh, eight insect and non-insect-pest species have been recorded associated with tomato under protected cultivation, amongst them; T. vaporariorum is the key pest (Sood et al., 2012). Adults and nymphs of T. vaporariorum suck phloem sap and results in weakening of host plant, while their honeydew secretion creates favourable conditions for the development of sooty mould that reduces plant photosynthesis. Under protected environment, greenhouse whitefly breeds throughout year and completes thirteen generations in a year (Sood et al., 2014). The favourable abiotic conditions and availability of tender plant parts for longer duration accompanied with more number of generations makes the management of $T$. vaporariorum more difficult. It needs more number of insecticidal applications to suppress the incidence, which leads to undesirable pesticide residues, killing of non-target organisms and development of resistance in $T$. vaporariorum to pesticides (van Lenteren, 2000; Sood et al., 2006; Pilkington et al., 2010; Pappas et al., 2013). Recently, an aphelinid parasitoid, Encarsia formosa Gahan (Hymenoptera: Aphelinidae) was found parasitizing greenhouse whitefly nymphs at Palampur, representing mid-hills of Himachal Pradesh. Encarsia formosa is used worldwide for commercial control of whiteflies in greenhouse crops. The present investigations were conducted to study the effect of insecticide based modules being evaluated for the management of $T$. vaporariorum on build-up of $E$. formos $a$ and to determine the relative safety of modules in tomato under protected environment. 


\section{MATERIALS AND METHODS}

The aphelinid parasitoid was first noticed during 2014 in tomato crop planted under protected environment at Palampur, $1290 \mathrm{~m}$ asl, representing mid-hills of Himachal Pradesh. Black mummified nymphs of Trialeurodes vaporariorum observed on mature leaves were collected and brought to the laboratory for emergence of adult parasitoids (Figure 1). The emerged adults were collected and preserved in 70 per cent ethanol and sent to Dr Mohammad Hayat, Department of Zoology, Aligarh Muslim University, Aligarh, India, for determining the identity.
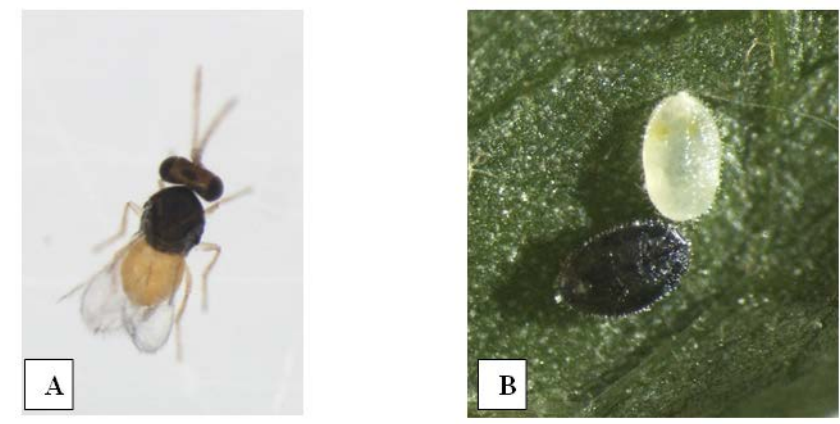

Fig. 1. A. Adult Encarsia formosa; B. Healthy and parasitized (black) nymphs of Trialeurodes vaporariorum.

Observations on buildup of Encarsia formosa were recorded in an experiment where insecticide based modules were being evaluated for the management of T. vaporariorum. Eight insecticide based modules comprising soil application of imidacloprid at transplanting and foliar applications of azadirachtin, spiromesifen and thiamethoxam were formulated (Table 1) and evaluated for the management of greenhouse whitefly on tomato grown under naturally ventilated polyhouse. All the insecticides evaluated were recommended and approved for use in tomato crop by Central Insecticides Board and Registration Committee, Government of India. The studies on extent of parasitization by $E$. formosa were undertaken in summer cropping season (March-July) during 2015 and 2016.

During 2015, activity of E. formosa was observed in eight management modules, where the adults of T. vaporariorum were released in large numbers at transplanting to initiate early buildup of the pest. Observations on parasitization of greenhouse whitefly immature (nymphs and pupae) were recorded 90 and 120 Days after Transplanting (DAT). Whereas, during 2016, four modules resulting in better suppression of greenhouse whitefly and higher tomato fruit yield were selected and evaluated. Also, adult greenhouse whiteflies were not released in early crop growth stage and the natural buildup of the pest was allowed. Observations on extent of parasitization of $E$. formosa were initiated with the first appearance of mummified immatures of greenhouse whitefly and continued till final harvesting of the crop at weekly interval.

Tomato cultivar Palam Tomato Hybrid-1 was raised in modified quonset naturally ventilated polyhouse $\left(250 \mathrm{~m}^{2}\right)$ by transplanting one month old seedlings in raised beds $(90$ $\mathrm{cm}$ wide) with plant to plant and row to row spacing of $30 \mathrm{~cm}$ and $70 \mathrm{~cm}$, respectively. Plants were trained on two stems. There were 24 plants in each management module (plot size: $4 \mathrm{~m} \times 0.9 \mathrm{~m}$ ) which were replicated thrice in a randomized block design.

Healthy and mummified nymphs and pupae of greenhouse whitefly were counted in lower and middle plant canopy from randomly selected five plants and per cent parasitization was worked out as per the following formula:

\section{Parasitization (\%)}

Number of mummified nymphs of greenhouse whitefly $=\frac{\text { Number of healthy nymphs }+ \text { Number of mummified nymphs }}{\text { num }} \times 100$

\section{RESULTS AND DISCUSSION}

\section{Taxonomy}

\section{Encarsia formosa Gahan (Figure 2 (A-G))}

Enacrsia formosa Gahan, 1924: 14, female. USA, Idaho, Twin Falls.

Encarsia formosa Gahan: Huang and Polaszek, 1998: 1881-1882, female, male, diagnosis, figures. Schmidt and Polaszek, 2007: 2165-2167, female, male, diagnosis, figures. Myartseva et al., 2012: 185-186, female, diagnosis, figures.

\section{Diagnosis}

Female. Length, $0.64-0.73 \mathrm{~mm}$. Head dark brown, ocellar area blackish; post-ocellar bars blackish. Mandible apically dark brown. Antenna with scape pale yellow; pedicel brown; funicle pale yellow; clava with first segment yellow, second segment brown. Mesosoma dark brown, with expanded part of side lobe of mesoscutum white. Wings hyaline; fore wing with submarginal vein brown; costal cell in about basal half infuscate brown. Legs pale yellowish white; fore coxa basally brown; hind coxa in about basal third dark brown. Metasoma with petiole dark brown; gaster white, at most tergite 1 (TI) narrowly across base pale brown.

Head (Figure $2 \mathrm{~A}$ ) with frontovertex width more than half of head width; head with the usual medio-frontal, transverse and lateral lines; sculpture and setation as in Fig. $2 \mathrm{~A}$; eye setose, setae hyaline, each seta longer than a facet diameter. Mandible (Figure $2 \mathrm{~B}$ ) with 2 teeth and a dorsal truncation. Maxillary and labial palps each 1-segmented. 
Antennal formula, 1142 (Figure 2 C); first funicle segment (F1) slightly shorter than to as long as pedicel, and about $2 \times$ as long as broad; F2-F4 each at least about $3 \times$ as long as broad, each clearly longer than F1; clava 2-segmented.

Mesosoma with sculpture as in (Figure $2 \mathrm{D}$ and $\mathrm{E}$ ); setae on tergites as follows: pronotal collar with $5+5$ setae, and a long seta at each postero-lateral corner; mid lobe of mesoscutum with 18 setae; each side lobe with 3 setae; each axilla with 1 seta, situated near to mesal margin in anterior third; scutellum with $4(2+2)$ setae, anterior pair separated by a distance slightly greater than distance between posterior pair; scutellar sensilla distantly placed, nearer to each anterior seta; propodeum with 2 setae distal to each spiracle. Fore wing (Figure 2 F) $2.6 \times$ as long as broad; marginal fringe $0.26 \times$ wing width; submarginal vein with 2 setae; one seta on parastigma; 8 setae on marginal vein; basal cell with 4 setae; marginal vein clearly longer than costal cell; postmarginal vein absent; stigmal vein thin. Hind wing (Figure $2 \mathrm{G}$ ) about $7.5 \times$ as long as broad; marginal fringe slightly longer than wing width. Mid leg (Figure 2 D) with tarsus 4-segmented; mid tibial spur slightly shorter than half the length of mid basitarsus.

Metasoma (Figure 2D) with petiole smooth; gaster with setae on tergites 1-7 (TI-TVII) as follows: TI, $0+0$; TII-TIV, $1+1$ each; TV, $1+2+1$; TVI, $1+2+1$ (outer seta each situated proximal to cercal plate, and 2 setae median); TVII, 4; ovipositor with second valvifer $1.54 \times$ as long as third valvula (ovipositor subequal in length to mid tibia; third valvula slightly longer than mid basitarsus, and $2.33 \times$ as long as mid tibial spur).

\section{Male Not obtained in our collection.}

Material examined: Several females, with 11 females on 5 slides (slide Nos. 641.E-645.E): INDIA: Himachal Pradesh: Palampur, 14.ix.2016, coll. Vinay Singh. ex Trialeurodes vaporariorum on crops under protected environment (ZDAMU-Insect Collections, Department of Zoology, Aligarh Muslim University, Aligarh)

Comments: Encarsia formosa Gahan is cosmopolitan in distribution, and is being recorded for the first time from India. E. formosa was first described from the specimens reared from an unidentified aleyrodid on geranium in 1924 in a greenhouse in Idaho, United States (Gahan, 1924). It parasitizes at least 15 hosts in eight aleyrodid genera (Hoddle et al., 1998). Around eighty species under the genus Encarsia Förster, 1878 are known from India (Hayat, 1998; Hayat, 2011; Poorani et al., 2015; Noyes, 2016) except E. formosa. Earlier, fifty five natural enemies comprising predators (24), parasitoids (21) and pathogens (10) have been recorded associated with $T$. vaporariorum from different parts of the globe (CABI, 2016). In India, eight natural enemies constituting three parasitoids [Encarsia inaron (Walker), E. sophia (Girault and Dodd) and Eretmocerus sp.], three coccinellids [Coccinella septempunctata Linn., Serangium haleemae Afroze and Haider and $S$. montazerii Fürsch], a chrysopid [Chrysoperla carnea (Stephens)] and a predatory mite [Amblyseius (Euseius) delhiensis (Narayanan \& Kaur)] have been found associated with greenhouse whitefly (Afroze and Haider, 1999; Kumar and Gupta, 2006; Chauhan et al., 2007; Reecha, 2010).
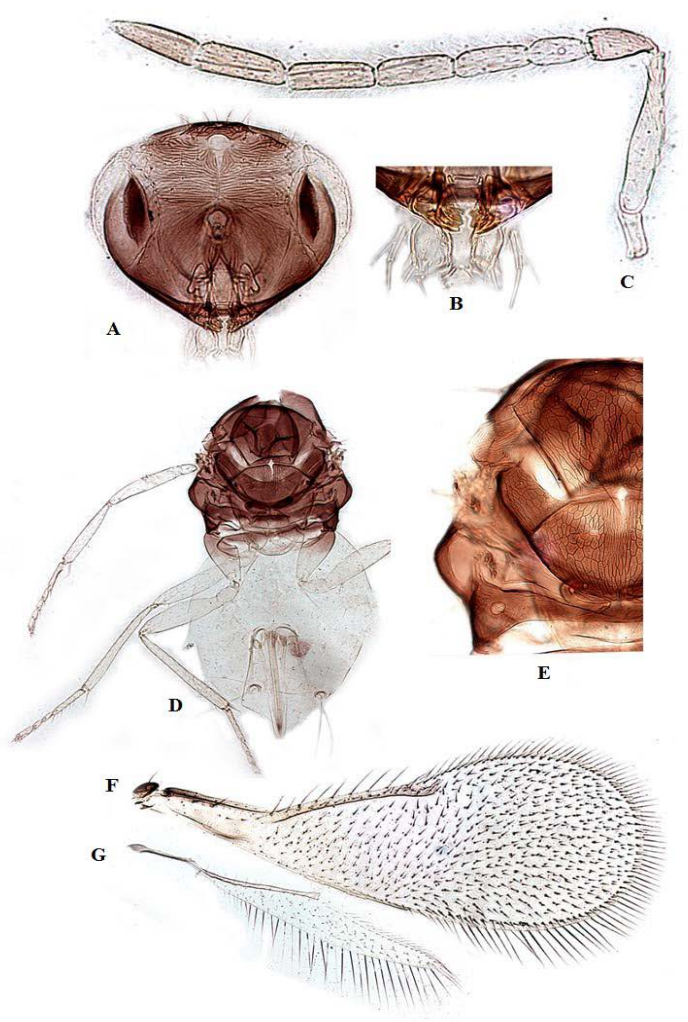

Fig. 2. A-G. Encarsia formosa Gahan, female. A. Head, frontal view; B. Mandibles and palps; C. Antenna; D. Mesosoma and metasoma, with legs of left side; $E$. Part of mesosoma showing sculpture and setation; F. Fore wing; G. Hind wing.

\section{Dynamics of Encarsia formosa on Tomato}

During 2015, parasitization by E. formosa varied from 3.92 to 25.46 and 19.32 to 81.21 per cent in different modules evaluated on 90 and 120 DAT, respectively with the corresponding parasitization of 31.78 and 93.33 per cent in Untreated Check (UC) (Table 1). In UC, significantly higher parasitization was recorded as compared to insecticidal modules. Parasitization was significantly higher in $\mathrm{M}_{4}$ (soil application of imidacloprid 1 DAT followed by foliar application of azadirachtin started at 45 DAT at 10 days 
interval) as compared to other modules. It was followed by $\mathrm{M}_{2}$ (soil applications of imidacloprid 1 DAT and 45 DAT). Whereas, the module comprising soil application of imidacloprid 1 DAT followed by alternate foliar applications of spiromesifen and thiamethoxam starting 45 DAT $\left(\mathrm{M}_{7}\right)$ resulted in significantly lowest parasitization. Whereas, during 2016, four efficacious modules namely, $M_{2}, M_{4}, M_{7}$ and $\mathrm{M}_{8}$ were selected and evaluated. A perusal of data presented in Table 2 revealed that the activity of $E$. formosa was first recorded 82 DAT in UC with the corresponding parasitization of 36.76 per cent. On 89 DAT, parasitization was also evident in $\mathrm{M}_{2}$ and $\mathrm{M}_{4}$. The module $\mathrm{M}_{7}$ remained free of greenhouse whitefly throughout the cropping season and was not included for statistical analysis. Based on mean parasitization observed on different dates of observations, it was observed that significant increase was evident from 96 to $124 \mathrm{DAT}$, with the maximum parasitization occurring in UC. Amongst the selected modules, $\mathrm{M}_{4}$ (Soil application of imidacloprid followed by foliar application of azadirachtin starting at 45 DAT at 10 days interval) resulted in significantly higher parasitization followed by $\mathrm{M}_{2}$ and $\mathrm{M}_{8}$, which were on a par to each other.
Based on the outcome of two cropping seasons, it was evident that the activity of $E$. formosa was evident in later part of the crop growth (80-90 DAT) and untreated check resulting in significantly higher parasitization as compared to greenhouse whitefly management modules. Amongst different modes, the modules comprising soil application of imidacloprid followed by foliar application of azadirachtin proved relatively safe for the buildup of E. formosa.

Neonicotinoids are conventionally thought to be nonlethal to beneficial insects when applied as soil treatment instead of direct foliar sprays (Ruberson et al., 1998; Krischik et al., 2007) unless they feed on plant tissue or excretions or are exposed to the pesticide via food chain toxicity (Prabhaker, et al. 2011). However, Koppert (2016) on the compatibility of insecticides and biological control organisms revealed that toxicity of imidacloprid (both spray and soil drench) and thiamethoxam (spray) to E. formosa persists for a period of around 12 weeks after application. In present investigations it has been observed that activity of E. formosa starts after 12 weeks (of treatment and transplanting) and skips the persistent period of imidacloprid toxicity, if any.

Table 1. Parasitization of Trialeurodes vaporariorum by Encarsia formosa in different management modules in summer crop during 2015

\begin{tabular}{|c|c|c|c|c|}
\hline \multirow{2}{*}{\multicolumn{2}{|c|}{ Insecticide based module }} & \multicolumn{3}{|c|}{$\begin{array}{l}\text { Parasitization (\%) on indicated days after trans- } \\
\text { planting (DAT) }\end{array}$} \\
\hline & & \multirow{2}{*}{$\begin{array}{l}90 \\
13.02 \\
(21.13)\end{array}$} & \multirow{2}{*}{$\begin{array}{l}120 \\
73.95 \\
(60.18)\end{array}$} & \multirow{2}{*}{$\begin{array}{l}\text { Mean } \\
43.48 \\
(40.66)\end{array}$} \\
\hline $\mathrm{M}_{1}$ & Soil application of imidacloprid $(0.009 \%) 1 \mathrm{DAT}$ & & & \\
\hline $\mathrm{M}_{2}$ & Soil application of imidacloprid $(0.009 \%) 1 \mathrm{DAT}$ and 45 DAT & $\begin{array}{l}9.78 \\
(18.22)\end{array}$ & $\begin{array}{l}82.04 \\
(65.81)\end{array}$ & $\begin{array}{l}45.91 \\
(42.01)\end{array}$ \\
\hline $\mathrm{M}_{3}$ & $\begin{array}{l}\text { Foliar application of azadirachtin }(0.00045 \%) \text { at } 10 \text { days interval } \\
\text { starting with10 DAT }\end{array}$ & $\begin{array}{l}8.75 \\
(17.14) \\
\end{array}$ & $\begin{array}{l}47.06 \\
(43.27) \\
\end{array}$ & $\begin{array}{l}27.90 \\
(30.20) \\
\end{array}$ \\
\hline $\mathrm{M}_{4}$ & $\begin{array}{l}\text { Soil application of imidacloprid }(0.009 \%)+\text { foliar application of } \\
\text { azadirachtin }(0.00045 \%) \text { starting at } 45 \text { DAT at } 10 \text { days interval }\end{array}$ & $\begin{array}{l}25.46 \\
(30.24) \\
\end{array}$ & $81.21(64.69)$ & $\begin{array}{l}53.34 \\
(47.47) \\
\end{array}$ \\
\hline $\mathrm{M}_{5}$ & $\begin{array}{l}\text { Alternate foliar applications of spiromesifen }(0.02 \%) \text { and thia- } \\
\text { methoxam }(0.01 \%) \text { at } 15 \text { days interval starting } 15 \text { DAT }\end{array}$ & $\begin{array}{l}7.69 \\
(16.01)\end{array}$ & $\begin{array}{l}69.54 \\
(56.62)\end{array}$ & $\begin{array}{l}38.62 \\
(36.31)\end{array}$ \\
\hline $\mathrm{M}_{6}$ & $\begin{array}{l}\text { Alternate foliar applications of spiromesifen }(0.02 \%) \text { and thia- } \\
\text { methoxam }(0.01 \%) \text { at } 15 \text { days interval when population goes } \\
\text { beyond } 5 \text { adults/leaf }\end{array}$ & $\begin{array}{l}10.18 \\
(18.54)\end{array}$ & $\begin{array}{l}35.90 \\
(36.76)\end{array}$ & $\begin{array}{l}23.04 \\
(27.65)\end{array}$ \\
\hline $\mathrm{M}_{7}$ & $\begin{array}{l}\text { Soil application of imidacloprid }(0.009 \%) 1 \text { DAT }+ \text { alternate foliar } \\
\text { applications of spiromesifen }(0.02 \%) \text { and thiamethoxam }(0.01 \%) \\
\text { starting } 45 \text { DAT }\end{array}$ & $\begin{array}{l}3.92 \\
(11.37)\end{array}$ & $\begin{array}{l}19.32 \\
(26.04)\end{array}$ & $\begin{array}{l}11.62 \\
(18.70)\end{array}$ \\
\hline $\mathrm{M}_{8}$ & $\begin{array}{l}\text { Soil application of imidacloprid }(0.009 \%) 1 \text { DAT }+ \text { alternate foliar } \\
\text { applications of spiromesifen }(0.02 \%) \text { and thiamethoxam }(0.01 \%) \\
\text { starting } 45 \text { DAT when population goes beyond } 5 \text { adults/leaf }\end{array}$ & $\begin{array}{l}13.58 \\
(21.59)\end{array}$ & $\begin{array}{l}61.76 \\
(51.78)\end{array}$ & $\begin{array}{l}37.67 \\
(36.69)\end{array}$ \\
\hline \multirow[t]{2}{*}{$\mathrm{UC}$} & Untreated check & $\begin{array}{l}31.78 \\
(34.26)\end{array}$ & $\begin{array}{l}93.33 \\
(76.13)\end{array}$ & $\begin{array}{l}62.56 \\
(55.20)\end{array}$ \\
\hline & Mean & $\begin{array}{l}13.80 \\
(20.94)\end{array}$ & $\begin{array}{l}62.68 \\
(53.48)\end{array}$ & \\
\hline
\end{tabular}

Figures in parenthesis are the arcsine transformed values $\mathrm{CD}(\mathrm{P}=0.05)$

Days after transplanting (A) : : : 2.74

Module (B) $\quad: 5.82$

$\mathrm{A} \times \mathrm{B} \quad: 8.22$ 
Table 2. Parasitization of Trialeurodes vaporariorum by Encarsia formosa in selective management modules in summer crop during 2016

\begin{tabular}{|c|c|c|c|c|c|c|c|c|c|c|}
\hline \multirow{2}{*}{\multicolumn{2}{|c|}{ Insecticide module }} & \multicolumn{9}{|c|}{ Parasitization (\%) on indicated days after transplanting (DAT) } \\
\hline & & 75 & 82 & 89 & 96 & 103 & 110 & 117 & 124 & Mean \\
\hline $\mathrm{M}_{2}$ & $\begin{array}{l}\text { Soil applications of } \\
\text { imidacloprid }(0.009 \%) \\
1 \text { DAT and } 45 \text { DAT }\end{array}$ & $*$ & $*$ & 12.50 & $\begin{array}{l}10.62 \\
(3.41)\end{array}$ & $\begin{array}{l}25.83 \\
(4.89)\end{array}$ & $\begin{array}{l}37.01 \\
(6.17)\end{array}$ & $\begin{array}{l}40.64 \\
(6.45)\end{array}$ & $\begin{array}{l}64.08 \\
(8.07)\end{array}$ & $\begin{array}{l}35.64 \\
(5.80)\end{array}$ \\
\hline $\mathrm{M}_{4}$ & $\begin{array}{l}\text { Soil application of } \\
\text { imidacloprid }(0.009 \%) \\
+ \text { foliar applica- } \\
\text { tion of azadirachtin } \\
(0.00045 \%) \text { starting } \\
\text { at } 45 \text { DAT at } 10 \text { days } \\
\text { interval }\end{array}$ & $*$ & $*$ & 30.00 & $\begin{array}{l}37.65 \\
(1.00)\end{array}$ & $\begin{array}{l}35.00 \\
(5.57)\end{array}$ & $\begin{array}{l}36.12 \\
(6.72)\end{array}$ & $\begin{array}{l}36.12 \\
(7.11)\end{array}$ & $\begin{array}{l}49.98 \\
(7.11)\end{array}$ & $\begin{array}{l}38.97 \\
(6.31)\end{array}$ \\
\hline $\mathrm{M}_{7}$ & $\begin{array}{l}\text { Soil application of } \\
\text { imidacloprid }(0.009 \%) \\
1 \text { DAT + alternate } \\
\text { foliar applications of } \\
\text { spiromesifen }(0.02 \%) \\
\text { and thiamethoxam } \\
(0.01 \%) \text { starting } 45 \\
\text { DAT }\end{array}$ & $*$ & * & * & * & * & * & * & * & $*$ \\
\hline $\mathrm{M}_{8}$ & $\begin{array}{l}\text { Soil application of } \\
\text { imidacloprid }(0.009 \%) \\
\text { 1 DAT + alternate } \\
\text { foliar applications of } \\
\text { spiromesifen }(0.02 \%) \\
\text { and thiamethoxam } \\
(0.01 \%) \text { starting } 45 \\
\text { DAT when population } \\
\text { goes beyond } 5 \text { adults/ } \\
\text { leaf }\end{array}$ & * & * & * & $\begin{array}{l}0.00 \\
(6.22)\end{array}$ & $\begin{array}{l}30.00 \\
(6.00)\end{array}$ & $\begin{array}{l}44.15( \\
6.09)\end{array}$ & $\begin{array}{l}49.50 \\
(6.09)\end{array}$ & $\begin{array}{l}49.50 \\
(7.14)\end{array}$ & $\begin{array}{l}34.63 \\
(5.50)\end{array}$ \\
\hline $\mathrm{UC}$ & Untreated check & 0.00 & 36.76 & 39.97 & $\begin{array}{l}73.15 \\
(8.61)\end{array}$ & $\begin{array}{l}76.66 \\
(8.81)\end{array}$ & $\begin{array}{l}89.02 \\
(9.49)\end{array}$ & $\begin{array}{l}92.86 \\
(9.68)\end{array}$ & $\begin{array}{l}93.58 \\
(9.73)\end{array}$ & $\begin{array}{l}85.05 \\
(9.26)\end{array}$ \\
\hline & & & & & $\begin{array}{l}30.36 \\
(4.81)\end{array}$ & $\begin{array}{l}41.87 \\
(6.31)\end{array}$ & $\begin{array}{l}51.58 \\
(7.12)\end{array}$ & $\begin{array}{l}54.78 \\
(7.33)\end{array}$ & $\begin{array}{l}64.29 \\
(8.01)\end{array}$ & \\
\hline
\end{tabular}

* No whitefly incidence occurred and not included in statistical analysis

Figures in parenthesis are the arcsine transformed values $\mathrm{CD}(\mathrm{P}=0.05)$

$\begin{array}{ll}\text { Days after transplanting (A) } & : 0.42 \\ \text { Module (B) } & : 0.38 \\ \mathrm{~A} \times \mathrm{B} & : 0.85\end{array}$

Present findings, the neem based module to result in significantly high parasitization draws support from the observations recorded by Feldhege and Schmutterer (1993) who also found azadirachtin (Margosan-O) to be selective for $E$. formosa. Simmonds (2002) observed a significant mortality of whitefly nymphs with no adverse effect on E. formosa emerging from them. Also Yankoval et al. (2011) observed neem based product BioNeem Plus 1.5 EC (azadirachtin) to be non-toxic to $E$. formosa.

Spiromesifen is generally classified as non-lethal to many natural enemies and was also proved harmless to the emergence of $E$. smithi from tea spiny whitefly Aleurocanthus camelliae (Ozawa and Uchiyama, 2014). Koppert (2016) also has classified spiromesifen as harmless or slightly harmful to E. formosa adults with no persistent toxicity. But in present investigations use of spiromesifen alongwith thiamethoxam (which is generally categorized as very harmful) might be the reason for lower activity of the parasitoid in related modules.

Encarsia formosa is a potential candidate to be exposed for inclusion in greenhouse whitefly management programme 
under protected cultivation. Also the safety of insecticides/ biopesticides needs to be determined for evolving a compatible plan.

\section{ACKNOWLEDGEMENTS}

We sincerely acknowledge the contribution of Dr Mohammad Hayat, Department of Zoology, Aligarh Muslim University, Aligarh, India, for determining the identity, providing diagnosis and detailed photograph (Fig. 2) of the parasitoid.

\section{REFERENCES}

Afroze S, Haider AA. 1999. A new species of genus Serangium Blackburn (Coccinellidae) from India. $J$ Insect Sci.12(2): 138-139.

Byrne DN, Bellows TS. 1991. Whitefly biology. Ann Rev Entomol. 36: 431 -457. https://doi.org/10.1146/annurev. en.36.010191.002243

CABI. 2016. Invasive Species Compendium. Centre for Agriculture and Biosciences International. Trialeurodes vaporariorum (whitefly, greenhouse). Available from: http:/www.cabi.org/isc/datasheet/54660. (accessed on October 26, 2016).

Chauhan U, Thakur M, Kadu S. 2007. Amblyseius (Euseius) delhiensis (Narayanan and Kaur) - a predator of whitefly on rose. Insect Environ. 13(1): 28-29.

Feldhege M, Schmutterer H. 1993. Investigations on sideeffects of Margosan-O on Encarsia formosa Gah. (Hym., Aphelinidae), parasitoid of the greenhouse whitefly, Trialeurodes vaporariorumWestw. (Hom., Aleyrodidae). J Appl Entomol. 115(1): 37-42. https:// doi.org/10.1111/j.1439-0418.1993.tb00361.x

Gahan AB. 1924. Some new parasitic Hymenoptera with notes on several described forms. Proceedings of the United States National Museum. 65:1-23. https://doi. org/10.5479/si.00963801.2517

Hayat M. 1998. Aphelinidae of India (Hymenoptera: Chalcidoidea): A taxonomic revision. Memoirs of Entomology, International. Volume 13. Associated Publishers, Gainesville, Florida. 416 pp.

Hayat M. 2011. Additions to the Indian Aphelinidae (Hymenoptera: Chalcidoidea) - III: the genus Encarsia Forster. Oriental Insects 45(2-3): 202-274. https://doi. org/10.1080/00305316.2011.630212

Hoddle MS, Van Driesche RG, Sanderson JP. 1998. Biology and use of the whitefly parasitoid Encarsia formosa.
Ann Rev Entomol. 43: 645-669. https://doi.org/10.1146/ annurev.ento.43.1.645 PMid:15012401

Huang J, Polaszek A. 1998. A revision of the Chinese species of Encarsia Förster (Hymenoptera: Aphelinidae): parasitoids of whiteflies, scale insects and aphids (Hemiptera: Aleyrodidae, Diaspididae, Aphidoidea). $J$ Nat Hist. 32: 1825-1966. https://doi.org/10.1603/0046225X(2007)36[1238:SIITTN]2.0.CO;2

Koppert. 2016. Koppert Biological Systems. Available from: https://www.koppert.com/ (accessed on October 23, 2016).

Krischik VA, Landmark AL, Heimpel GE. 2007. Soil-applied imidacloprid is translocated to nectar and kills nectar feeding Anagyrus pseudococci (Girault) (Hymenoptera: Encyrtidae). Environ Entomol. 36(5): 1238-1245. https://doi.org/10.1603/0046-225X\%282007\%2936\%5 B1238:SIITTN.5D2.0.CO.3B2

Kumar R, Gupta PR. 2006. Natural enemies associated with the greenhouse whitefly, Trialeurodes vaporariorum (Westwood), on vegetable crops in the mid-hill region of Himachal Pradesh. Pest Mgmt Econ Zool. 14(1/2):73-78.

Myartseva SN, Cancino ER, Blanco JMC. 2012. Aphelinidae (Hymenoptera: Chalcidoidea) de importancia agrícola en México. Revision y claves. Serie Avispas Parasíticas de Plagas y Otros Insectos. 8: 1-396.

Noyes JS. 2016. Universal Chalcidoidea Database. World Wide Web electronic publication. Available from: http:// www.nhm.ac.uk/chalcidoids

Ozawa A, Uchiyama T. 2014. Effects of several insecticides on the emergence of Encarsia smithi (Silvestri) parasitizing the tea spiny whitefly, Aleurocanthus camelliae Kanmiya \& Kasai. Annu Rep Kanto-Tosan Pl Prot Soc. 61: $159-162$.

Pappas ML, Migkou F, Broufas GD. 2013. Incidence of resistance to neonicotinoid insecticides in greenhouse populations of the whitefly, Trialeurodes vaporariorum (Hemiptera: Aleyrodidae) from Greece. Appl Entomol Zool. 48(3): 373-378. https://doi.org/10.1007/s13355013-0197-z

Pilkington LJ, Messelink G, van Lenteren JC,Mottee KL. 2010. Protected biological control: biological pest management in the greenhouse industry. Biol Control 52: 216-220. https://doi.org/10.1016/j.biocontrol.2009.05.022

Poorani J, Ramesh AK, Manickavasagam S and Malathi C. 2015. Indian Genera of Aphelinidae and its related fam- 
VINAY SINGH and SOOD

ilies. World Wide Web electronic publication. NBAIR (ICAR), Bangalore, India. Available from: http://www. nbair.res.in/Aphelinidae/index.php

Prabhaker N, Castle SJ, Naranjo SE, Toscano NC, Morse JG. 2011. Compatibility of two systemic neonicotinoids, imidacloprid and thiamethoxam, with various natural enemies of agricultural pests. J Econ Entomol. 104(3): 773-781. https://doi.org/10.1603/EC10362 PMid:21735893

Reecha. 2010. Exploitation of Aphelinidendoparasitoids, Encarsia sp. and Eretmocerus sp. and Entomopathogenic fungi for the suppression of greenhouse whitefly. Ph.D. Thesis. Dr Yashwant Singh Parmar University of Horticulture and Forestry; Solan. 94 p.

Ruberson JR, Nemoto H, Hirose Y. 1998. Pesticides and conservation of natural enemies in pest management, $\mathrm{pp}$. 207-220. In: Barbosa P. (Ed.), Conservation biological control. Academic, New York. https://doi.org/10.1016/ B978-012078147-8/50057-8

Schmidt S, PolaszekA. 2007. The Australian species of Encarsia Förster (Hymenoptera, Chalcidoidea: Aphelinidae), parasitoids of whiteflies (Hemiptera, Sternorrhyncha, Aleyrodidae) and armoured scale insects (Hemiptera, Coccoidea: Diaspididae). J Nat Hist. 41(32-36): 20992265. https://doi.org/10.1080/00222930701550766

Simmonds MSJ. 2002. Use of neem-derived products in an integrated pest management strategy in glasshouses. In: pp. 28-32. Cole M. and Strang R (Eds.). The Science and Application of Neem. Glasgow, Neemco.
Sood AK, Sood S. 2004. Host range and population dynamics of greenhouse whitefly, Trialeurodes vaporariorum (Westwood) in North Western Indian Himalayas. In: Proceedings XXII International Congress of EntomologyStrength in Diversity, Brisbane, Australia, 108.

Sood AK, Mehta PK, Verma KS, Sharma KD, Banyal DK, Chandel YS. 2012. Status of plant protection mechanism under protected cultivation in Himachal Pradesh. In: Indian Science Congress 2012, Bhubneswar, 154-155.

Sood AK, Sood S, Anjana D. 2014. Morphometrics and annual life cycle of greenhouse whitefly, Trialeurodes vaporariorum (Westwood) in Himachal Pradesh. Himachal J Agric Res. 40(1): 50-57.

Sood S, Sood AK, Verma KS. 2006. Determination of baseline toxicity of some insecticides to greenhouse whitefly, Trialeurodes vaporariorum (Westwood) population from North-Western Indian Himalyas. Pest Mgmt Econ Zool. 12(1): 67-70.

van Lenteren JC. 2000. A greenhouse without pesticides: fact or fantasy? Crop Prot. 19: 375-384. https://doi. org/10.1016/S0261-2194(00)00038-7

Yankoval V, Masheval S, Boevl B, Toskov K. 2011. Toxicity of plant protection products towards the imago of Encarsia formosa Gah. Agric Sci Technol. 3(4): 374 - 377. 